\title{
Co-seismic fault geometry and slip distribution of the 26 December 2004, giant Sumatra-Andaman earthquake constrained by GPS, coral reef, and remote sensing data
}

\author{
Yongge Wan $\cdot$ Zheng-kang Shen $\cdot$ Min Wang • \\ Yuehua Zeng · Jichao Huang • Xiang Li • \\ Huawei Cui · Xiwei Gao
}

Received: 29 January 2015/Accepted: 10 April 2015/Published online: 29 May 2015

(C) The Author(s) 2015. This article is published with open access at Springerlink.com

\begin{abstract}
We analyze co-seismic displacement field of the 26 December 2004, giant Sumatra-Andaman earthquake derived from Global Position System observations, geological vertical measurement of coral head, and pivot line observed through remote sensing. Using the co-seismic displacement field and AK135 spherical layered Earth model, we invert co-seismic slip distribution along the seismic fault. We also search the best fault geometry model to fit the observed data. Assuming that the dip angle linearly increases in downward direction, the postfit residual variation of the inversed geometry model with dip angles linearly changing along fault strike are plotted. The geometry model with local minimum misfits is the one with dip angle linearly increasing along strike from $4.3^{\circ}$ in top southernmost patch to $4.5^{\circ}$ in top northernmost path and dip angle linearly increased. By using the fault shape and geodetic co-seismic data, we estimate the slip distribution on the curved fault. Our result shows that the earthquake ruptured $\sim 200-\mathrm{km}$ width down to a depth of about $60 \mathrm{~km}$. $0.5-12.5 \mathrm{~m}$ of thrust slip is resolved with the largest slip
\end{abstract}

Y. Wan $(\bowtie) \cdot$ J. Huang $\cdot$ X. Li $\cdot$ H. Cui $\cdot$ X. Gao

Institute of Disaster-Prevention, Sanhe 065201, Hebei, China

e-mail: Wanyg217217@vip.sina.com

Z. Shen

Department of Earth and Space Sciences, University of

California, Los Angeles, CA 90095-1567, USA

M. Wang

Institute of Geology, China Earthquake Administration,

Beijing 100029, China

Y. Zeng

U. S. Geology Survey, Golden, CO 80401, USA centered around the central section of the rupture zone $7^{\circ} \mathrm{N}-10^{\circ} \mathrm{N}$ in latitude. The estimated seismic moment is $8.2 \times 10^{22} \mathrm{~N} \mathrm{~m}$, which is larger than estimation from the centroid moment magnitude $\left(4.0 \times 10^{22} \mathrm{~N} \mathrm{~m}\right)$, and smaller than estimation from normal-mode oscillation data modeling $\left(1.0 \times 10^{23} \mathrm{~N} \mathrm{~m}\right)$.

Keywords Sumatra-Andaman earthquake $\cdot$ Fault geometry $\cdot$ Co-seismic slip distribution · Geodetic data

\section{Introduction}

The 26 December 2004 Sumatra-Andaman megathrust earthquake was one of the largest earthquakes of the past century (Sieh 2005; Lay et al. 2005). This event ruptured a section of the Sumatra-Andaman subduction zone, separating the Australia and Sundaland plate in the south, and the India and Burma plate in the north (Simoes et al. 2004; Prawirodirdjo et al. 1997; Shearer and Bürgmann 2010). Approximately 300,000 human lives were lost as the result of this devastating earthquake and the tsunami it generated. Despite of its great size and catastrophic consequences, however, the magnitude and rupture distribution of the earthquake are still being debated. Early Harvard centroid moment solution using the first $500 \mathrm{~s}$ of seismic data suggested a seismic moment release of $M=$ $4.0 \times 10^{22} \mathrm{~N} \mathrm{~m}$, equivalent to $M_{\mathrm{W}} 9.0$ (http://www.global CMT.org). A subsequent study of normal-mode free oscillation data derived a seismic moment release of $1.0 \times 10^{23} \mathrm{~N} \mathrm{~m}$, equivalent to $M_{\mathrm{W}} 9.3$ (Stein and Okal 2005). The spatial distribution of aftershocks suggested that the earthquake ruptured a portion of the subduction zone of about $1400 \mathrm{~km}$ long, spanning $\sim 2^{\circ} \mathrm{N}-14^{\circ} \mathrm{N}$ in latitude. More detailed seismic waveform studies, using 
surface wave data, revealed that the slip was extended to the Andaman islands region, and the maximum slip appeared to have occurred south of $9.5^{\circ} \mathrm{N}$, along a segment of the plate interface offshore of the northwestern Sumatra and the southern Nicobar Islands (Ammon et al. 2005). The moment release was estimated $6.5 \times 10^{22} \mathrm{~N}$ m, equivalent to an $M_{\mathrm{W}} 9.15$ earthquake (Ammon et al. 2005). The same estimate was yielded also by Park et al. (2005) from free oscillation data modeling. Multiple source analysis by Tsai et al. (2005) specified 5 sources, 3 larger ones along the southern $\left(<9^{\circ} \mathrm{N}\right)$ segments, and 2 smaller ones along the northern $\left(>9^{\circ} \mathrm{N}\right)$ segments of the subduction zone, respectively. The total seismic moment was $1.17 \times 10^{23} \mathrm{~N} \mathrm{~m}$, equivalent to $M_{\mathrm{W}} 9.3$ (Tsai et al. 2005).

Although a lot have been learnt from the seismic studies mentioned above, determination of displacements along the northern segment of the fault was difficult because the seismic studies are less sensitive to slow slip, which, as evidence showed, was likely happened there ( $\mathrm{Ni}$ et al. 2004; Bilham 2005). Such a deficiency can be addressed by geodetic studies, as geodetic data usually measure displacements resulted from overall slip along a fault. Analyzing a GPS data set from continuous GPS tracking stations in the region of east Asia and around India Ocean, Banerjee et al. $(2005,2007)$ derived station co-seismic displacements induced by the earthquake, and used the data set to invert for fault slip. Their result suggested that although maximum slip was probably at the southern segment, significant slip took place along the northern part of the rupture zone, contributing to a total seismic moment release of $\sim 6 \times 10^{22} \mathrm{~N} \mathrm{~m}$, equivalent to $M_{\mathrm{W}} 9.2$. Their study, however, was done using mainly far-field data and could not provide detailed solution for slip distribution. Another geodetic study by Vigny et al. (2005) incorporated continuous GPS data from a network located in the Malai Peninsular, which strengthened observations in the intermediate field and enabled them to improve the spatial resolution of rupture distribution. Their result showed two peaks of slip along fault, spanning regions $4^{\circ} \mathrm{N}-7^{\circ} \mathrm{N}$ and $8^{\circ} \mathrm{N}-12^{\circ} \mathrm{N}$, respectively. The total moment release estimate was also equivalent to an $M_{\mathrm{W}} 9.2$ earthquake. By using campaign mode GPS measurements of co-seismic displacements at 13 sites in the Andaman-Nicobar Islands before and after the 2004 Sumatra-Andaman earthquake, Gahalaut et al. (2006) estimated co-seismic slip under the Andaman and Nicobar Islands as 3.8-7.9 m and 11-15 m, respectively. More co-seismic deformation data were obtained by Subarya et al. (2006), including GPS data acquired from the northern Sumatra island, sea floor vertical uplift/subsidence from coral reef measurements, and positions of pivot line from satellite image data around the Simeulue, Nicobar, and Andaman islands. Combined with GPS data of Vigny et al. (2005), they attempted two models: one after Ammon et al's (2005) fault geometry and the other approximating a curved fault plane. Both of the models deduced seismic moment of $8.8 \times 10^{22} \mathrm{~N} \mathrm{~m}$, corresponding to $M_{\mathrm{W}} 9.22$. If using Vigny's data only, their result is almost identical to that of Vigny's. They also show three distinct patches of high slip from $4^{\circ} \mathrm{N}$ to $6^{\circ} \mathrm{N}, 8^{\circ} \mathrm{N}$ to $10^{\circ} \mathrm{N}$, and $12^{\circ} \mathrm{N}$ to $13.75^{\circ} \mathrm{N}$.

These co-seismic studies described above differ in many ways, not only in data type and quantity but also in model parameterization. Among all the studies, Subarya et al. (2006) have ensembled the most complete geodetic dataset. Nevertheless, a more accurate slip model could be obtained if the following ingredients are incorporated in one model: (a) more data, from near to far field, (b) a layered spherical instead of flat half space Earth model for deformation modeling, and (c) more exploration of the parameter space in fault geometry. The last two items are especially important because precise flat Earth assumption can produce significant bias in modeling intermediate-far-field deformation and the slab geometry in the region is yet to be determined (Shearer and Bürgmann 2010).

\section{Data}

We ensemble a GPS data set from continuous and survey mode stations in the region to obtain the co-seismic displacement field. The data set is synthesized from several independent investigations. We collect over 3 years of GPS data (2002-01-01-2005-01-10) from the IGS stations located in Indonesia, Singapore, Philippine, India, Australia, and Guam, and sites from the Crustal Motion Observation Network of China (CMONOC) located in the mainland China and South China Sea (Niu et al. 2005). Forty days (2004-12-01-2005-01-09) of GPS data from a continuous network of 3 stations in the Sumatran GPS Array (SuGAr) (http://www.tectonics.caltech.edu/sumatra/data.html) at central Sumatra established by Caltech and Indonesian scientists are also included. One may argue that the preshocks and aftershocks occurred in the region might contaminate the GPS co-seismic displacement. So 1086 earthquakes are searched in rectangle region from 0 to $16^{\circ} \mathrm{N}$ and $90^{\circ} \mathrm{E}$ to $96^{\circ} \mathrm{E}$, from Advanced National Seismic System (ANSS). The moment released by all these earthquakes except the Sumatra-Andaman earthquake estimated as $9.8 \times 10^{19} \mathrm{~N} \mathrm{~m}$, which is three order smaller than the moment of the Sumatra-Andaman earthquake. The other argument is that post-seismic processes might contaminate the geodetic data. But Gahalaut et al. (2008) suggested that no large post-seismic deformation occurred in the 16-25 days period following the great earthquake. The GPS data were analyzed in four steps (Shen et al. 1994). First, the GPS carrier phase data were processed to obtain 
loosely constrained daily solutions for station positions and satellite orbits using the GAMIT software (King and Bock 2000). Second, the regional daily solutions were combined with global solutions produced by the Scripps Orbital and Position Analysis Center (SOPAC, http://sopac.ucsd.edu/) using the GLOBK software (Herring 2002). Third, all the pre-seismic daily solutions were aggregated together to estimate for the pre-seismic station positions and velocities through a Kalman filter procedure using the QOCA software (http://gipsy.jpl.nasa.gov/qoca/). The velocity solution is with respect to the global reference frame ITRF2000-NNR (Altamimi et al. 2002), which is realized by selecting a group of key global IGS sites and constraining their velocities to the ITRF2000-NNR values. Fourth, a subset of the combined daily solutions, 30 days immediately before and 10 days after the earthquake were used to derive the co-seismic offsets for the stations located in and around the northern Indian Ocean and in the east Asia area south of Siberia, with all the station velocities constrained to their estimates obtained from the previous step. Only three days of data immediately after the quake were used for stations SAMP and NTUS (Fig. 1) to leave out subsequent post-seismic displacements at the sites. The derived station co-seismic offsets are shown in Figs. 1 and 2 .

In the intermediate-far field, our result shows that station SAMP located on the northwest of the Sumatra island moved $135 \mathrm{~mm}$ west-southwesterly, and station NTUS located at Singapore moved $14 \mathrm{~mm}$ west-northwesterly (Fig. 1). Centimeter level displacements are also observed in southern India and South China Sea, with the Indian sites moved eastward and the South China Sea sites westsouthwestward, respectively. East-northeastward motion of around a centimeter is also observed at stations located in northern Indian Ocean. Millimeter level displacements are detected throughout south and east China, with the furthest observable sites at the level of a couple of millimeters located in North China which is almost $4000 \mathrm{~km}$ north of the earthquake epicenter. Co-seismic displacements are small in Australia, probably no more than a couple of millimeters at most, despite of its closer distance to the earthquake than south China. This is probably because these stations are located near the nodal plane of the rupture. Displacements at the 5 SuGAR sites were also small in view of their locations with respect to the earthquake rupture plane, which, again, is probably due to their proximity to the nodal plane of the rupture.

In addition to the data set mentioned above, we have included five other co-seismic data sets in this study. The first one is derived from GPS observations from a group of survey mode stations located in southeast Asia area, particularly in the Malaysian Peninsula (Vigny et al. 2005). This data set provides crucial constraints to the intermediate field of co-seismic deformation for this earthquake. Another data set is from Banerjee et al. (2005), who, like us, estimated co-seismic offsets of the IGS stations in the region, plus nine continuous stations in India. We do not use their results of the regional IGS sites since they are pretty much the same as ours, but incorporate the results from the nine India stations which are useful to constrain the northwest section of the co-seismic deformation of the quake. The third data set we incorporated in the study is from three survey mode stations located at the Andaman and Nicobar Islands, on the hanging wall of the Sumatra-Andaman subduction zone. The data were collected several years in a row before, and once after the megathrust event, by survey teams organized from the Center for Earth Science Studies (CESS), India. Their coseismic offsets are provided in the CESS website (http:// www.seires.net/content/view/122/52/), and show 2-6 m west-southwestward motions, respectively. The fourth data set is the 13 GPS campaign measurements on the Andaman and Nicobar Islands carried out by survey of India, which is used by Gahalaut et al. (2006); Banerjee et al. (2007) and Chlieh et al. (2007). The fifth data set is the 3-D co-seismic displacements derived from survey mode GPS data in Sumatra by Subarya et al. (2006). The last data set is vertical displacements obtained from coral reef measurements and pivot lines of satellite images reported also by Subarya et al. (2006) and Meltzner et al. (2006). Although this sort of data have large uncertainty (tens of centimeter), it can constrain the fault model for its near distance. All of the co-seismic offset results are showed in Figs. 1 and 2, and used for the inversion of co-seismic rupture distribution and fault geometry.

\section{Earthquake rupture geometry}

We use the co-seismic displacement data set derived above to invert for fault rupture which is devised as dislocation in a layered elastic media. A dislocation code modified from the one used in Zeng (2001) is employed to compute the Green's functions linking fault rupture to surface displacements. We also adopt the "Earth flattening" method (Biswas and Knopoff 1970) to accommodate the curvature effect of the Earth's surface, which is significant at the far field and should not be neglected (Banerjee et al. 2005). The fault model is composed of multiple tiles, 13 by 6 along strike and dip, respectively. Each tile spans $\sim 1^{\circ}$ latitude at trench and extends $\sim 40-\mathrm{km}$ down dip, with the dipping directions change gradually from NW in the south to ESE in the north. These tiles mesh the subduction slab interface in the aftershock zone $\sim 2^{\circ} \mathrm{N}-15^{\circ} \mathrm{N}$ latitude.

Although the horizontal scale of the rupture can be approximately constrained by aftershock distribution, the fault 


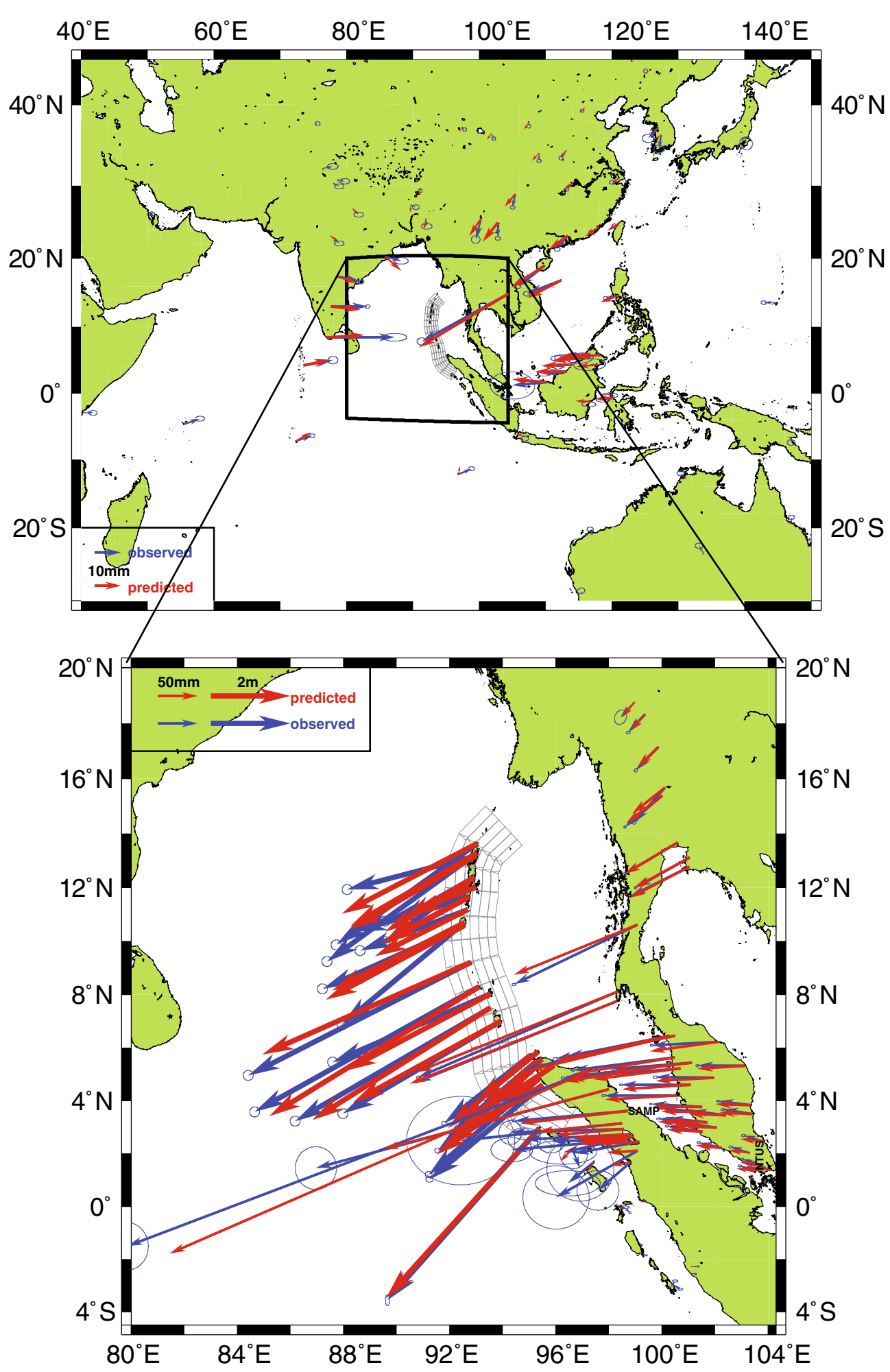

Fig. 1 The observed and predicted co-seismic horizontal displacement of the Sumatra-Andaman earthquake. The blue quivers are observed coseismic displacements with $95 \%$ error ellipses, and the red ones are predicted co-seismic displacements

dipping profile is not well constrained for this part of the plate boundary. In our model, we start with fault geometry close to that of Model B of Subarya et al. (2006). The dip angle increase linearly from south to north, from $\sim 24^{\circ}$ at the southernmost bottom patch to $\sim 38^{\circ}$ at the northernmost bottom patch (star in Fig. 4). The upper boundary of the top 

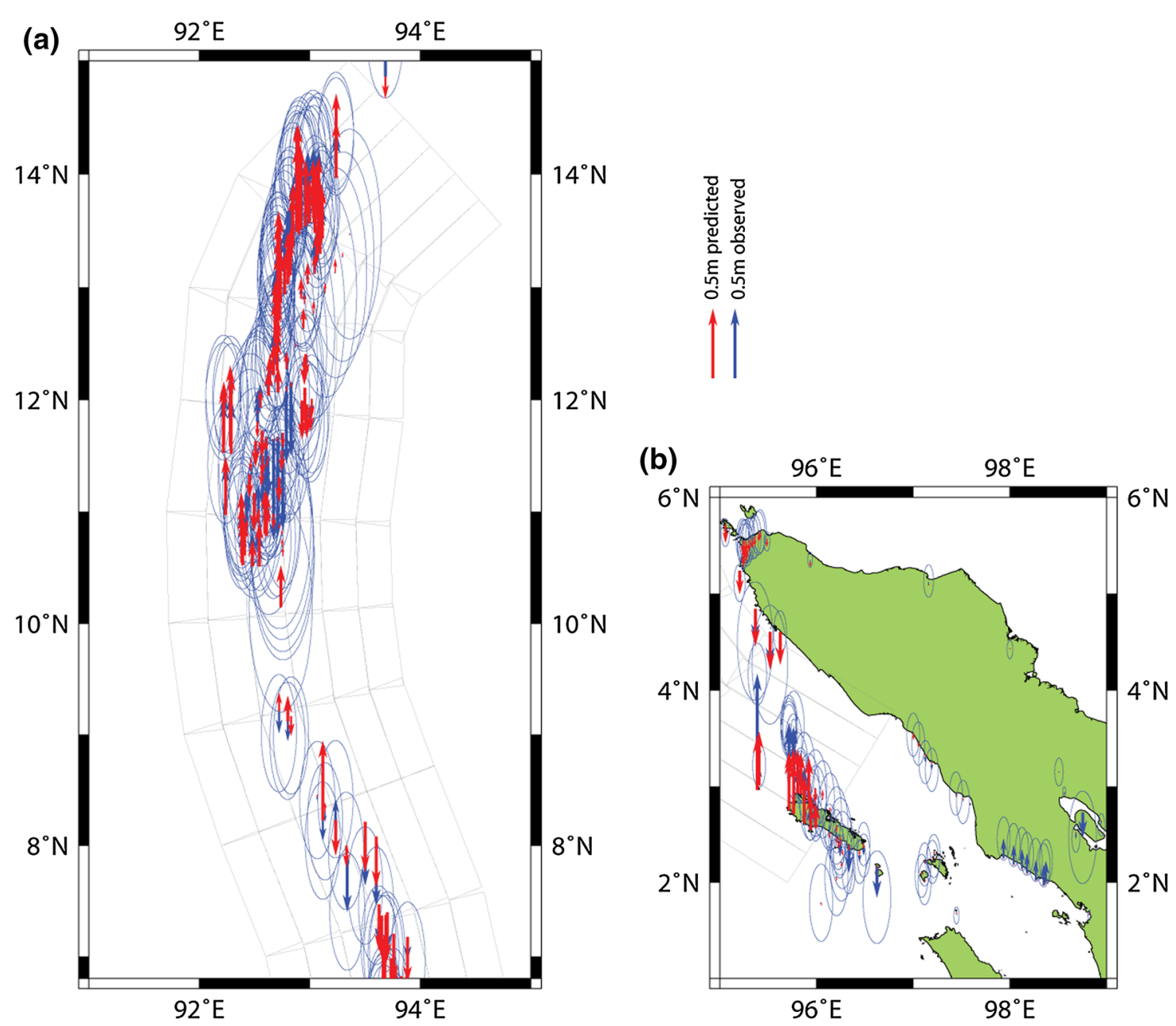

Fig. 2 The observed and predicted co-seismic vertical displacements of the Sumatra-Andaman earthquake. The blue quivers are observed coseismic displacements with $95 \%$ error ellipses, and the red ones are predicted co-seismic displacements. a North part; b South part

layer patches at trench is assumed at 4-km depth, taking into account the initial bending effect there. We then allow the dip angle to vary linearly both along strike and downward, and search for the optimal fault model through an iterative procedure. The best model corresponds to the one with the least data postfit residual $\chi^{2}$.

Assuming uniform slip at each tile, we invert the coseismic displacement data for slip on the tiles through a least-squares procedure. In the process, we have downweighted the data of the 16 Nicobar sites by enlarging their uncertainties to $200 \mathrm{~mm}$, to accommodate the fact that observations are mostly sensitive to the local slip along thrust interface beneath the stations which our averaged slip model does not have the corresponding resolution to account for. To stabilize the solution, we also impose firstorder smoothing to the fault slip components with finite uncertainty for both the along strike and dip components, respectively. Exact amount of the uncertainty for the a priori constraints is optimally determined through an iterative procedure, weighing a trade-off between the data postfit residual $\chi^{2}$ and the number of parameters resolved in the inversion, as shown in Fig. 3.

In Fig. 3, the line AC is the asymptote extrapolated from three of the largest postfit residual $\chi^{2}$ points, and the line $\mathrm{AD}$ is the asymptote extrapolated from three of the least postfit residual $\chi^{2}$ points. The point near to the cross point of the two asymptote lines is the best first order smoothing constraint (Wan et al. 2008). In this case we determine that the optimal model constraint corresponds to the uncertainty of the a priori smoothing constraint as $3.0 \mathrm{~m}$.

The second iteration process is to optimally estimate the dip angles of the bottom southernmost and northernmost patches, assuming the dip angle linearly increases in downward direction and fault strike direction. A series of inversions are performed assuming different dip angles with the uncertainty of the first order smoothing constraint assigned as $3.0 \mathrm{~m}$. The 2-D distribution of postfit residual $\chi^{2}$ as a function of the dip angles of the southernmost and northernmost bottom patches is shown as Fig. 4. We can see that the postfit residual $\chi^{2}$ is more sensitive to the dip 


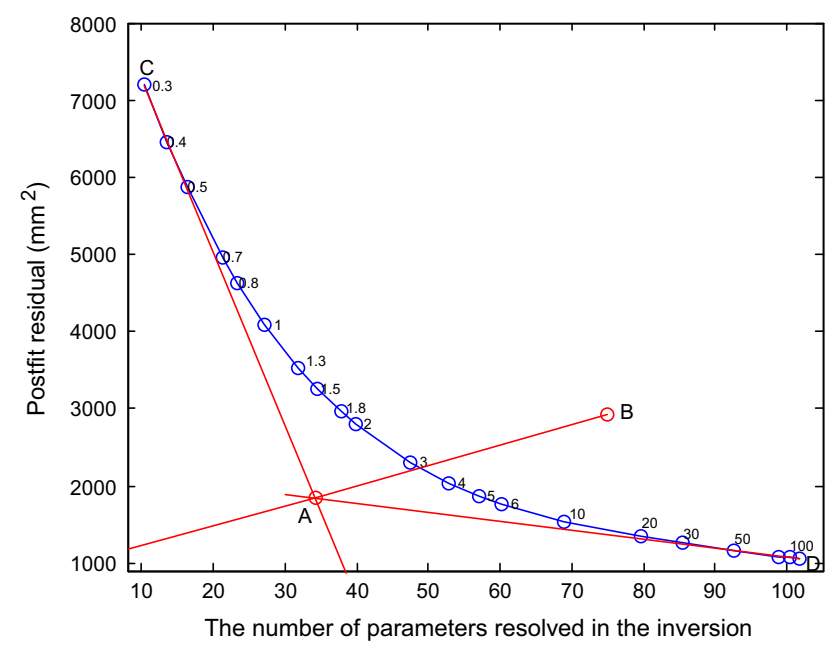

Fig. 3 The trade-off curve of the number of parameters resolved in the inversion versus postfit residual. The numbers in the figure are uncertainties of the first-order smoothing constraints (in meter)

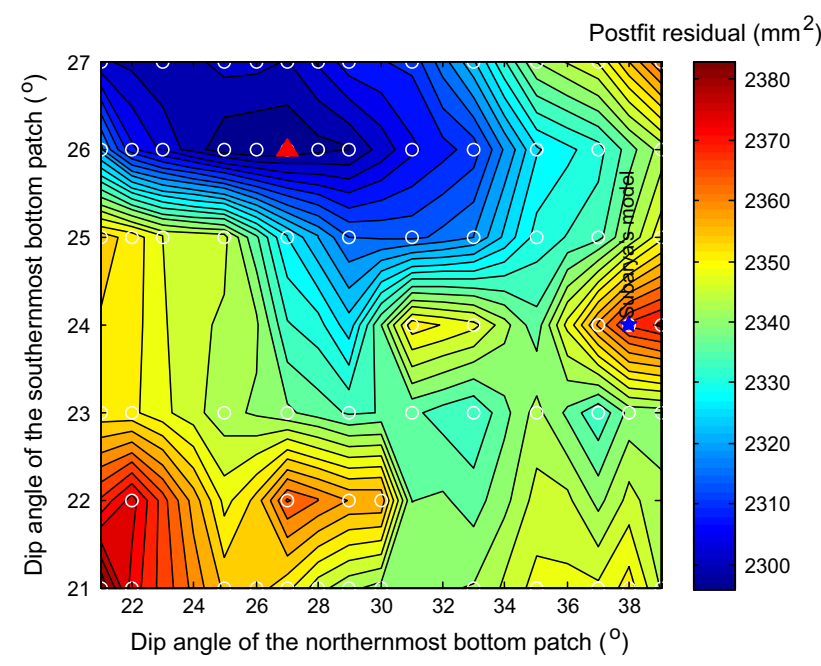

Fig. 4 Postfit residual $\chi^{2}$ variation with the dip angles of northernmost and southernmost patches. Every circle represents an inversion. Star represents the model of Subarya et al. (2006). Triangle represents the best solution searched in this study

angle of the southernmost bottom patch than that of the northernmost bottom patch. This may be caused by more densely near field observed data at the southern part of the rupture model (Figs. 1, 2). The model of Subarya et al. (2006) is not the one with the minimum postfit residual $\chi^{2}$, which is the significance of this study lies. Although large undulation of the postfit residual $\chi^{2}$, the global minimum postfit residual $\chi^{2}$ is found out at the value of $2296 \mathrm{~mm}^{2}$. The best model is the one with dip angle linearly increases along strike from $4.3^{\circ}$ in top southernmost patch to $4.5^{\circ}$ in top northernmost path and dip angle linearly increased in downward direction, which we used as the rupture zone and inverse the slip distribution.

\section{Slip distribution}

Based on the searched geometry model, as shown in Fig. 5, the slip distribution is obtained from all the geodetic measurements described above. The slip distribution shows dominant thrust components for all the patches, ranging $\sim 0.5-12.5 \mathrm{~m}$, with the largest slip centered around $9^{\circ} \mathrm{N}$ latitude and $\sim 10 \mathrm{~km}$ in depth (Fig. 5a). The shallow part of the rupture releases large part of the moment. Rupture is also accompanied with meter level right-lateral slip for the shallow part except the southernmost top patch and leftlateral slip in deep part of northern rupture zone and southernmost segment (Fig. 5b), which is consistent with the relative plate motion direction of the region (Prawirodirdjo et al. 1997). The largest left-lateral slip lies in the southernmost for the turning of the fault strike. A large right-lateral slip occurred in bottom patch at $\sim 6^{\circ} \mathrm{N}$ latitude, which is resulted from measurements near Banda Aceh, northwest end of Sumatra island (Figs. 1, 2). Figure $5 \mathrm{c}$ shows a fan-like pattern of the overall pattern of the slip distribution, which indicates stress directions accumulated on the fault before this large event.

Many slip distribution models have been published for the 2004 Sumatra earthquake constrained using seismic and/or geodetic data. Here we compare our model and results with that of the previous studies. We start our geometry model search with the model of Subarya et al. (2006). To our surprise, we found that their model is not the one with minimum postfit residual. Although the models of Ammon et al. (2005); Tsai et al. (2005); Subarya et al. (2006) and Rhie et al. (2007) place the largest peak rupture at the southmost of the aftershock zone, which is different from our slip model, Pietrzak et al. (2007) argued that the tsunami data favor models with slip maxima that are as high $(\sim 20 \mathrm{~m})$ in the northern portion (near $8^{\circ} \mathrm{N}-$ $\left.10^{\circ} \mathrm{N}\right)$ of the rupture as in the south $\left(3^{\circ} \mathrm{N}-5^{\circ} \mathrm{N}\right)$, which is supported by the studies of Gahalaut et al. (2006); Chlieh et al. (2007) and Banerjee et al. (2007). The largest peak rupture in our model placed at the latitude of $8^{\circ} \mathrm{N}-10^{\circ} \mathrm{N}$. This may be resulted from slow slip occurred at the largest peak zone in our model, which cannot be seismically resolved in the models of Ammon et al. (2005); Tsai et al. (2005) and Rhie et al. (2007). Although the geodetic determined models of Gahalaut et al. (2006); Chlieh et al. (2007) and Banerjee et al. (2007) can resolved the slow slip at the largest peak rupture in our model, lack of far-field data and densely distributed geodetic measurements in Aech and nearby will underestimate the slip value at this region. Constrained by near, intermediate, and far-field geodetic data, our model will reflect "reality" of the rupture. Six or more peak ruptures are resolved in the slip models of Chlieh et al. (2007) and Pietrzak et al. (2007) for their loosely smoothing constraints between adjacent 

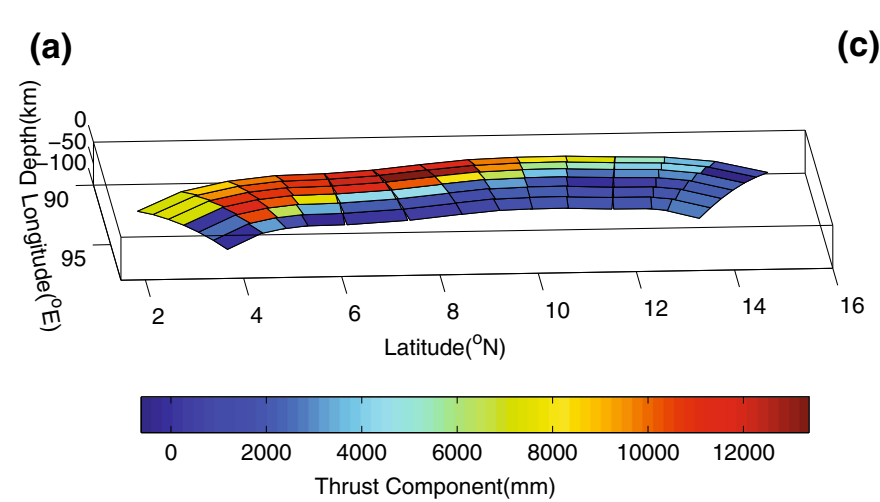

(b)
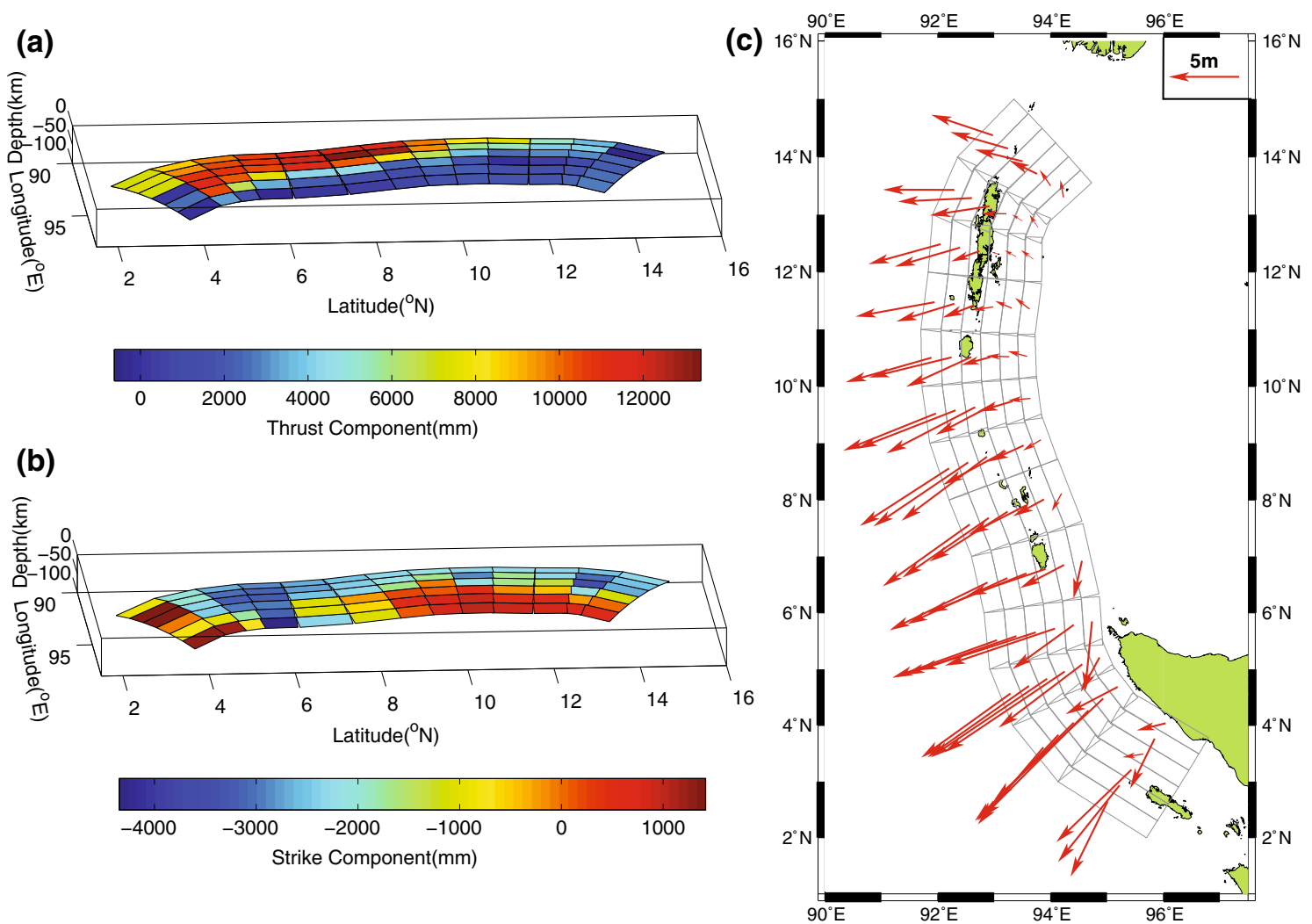

Fig. 5 Slip distribution on the fault plane. a Thrust component; b Strike slip distribution (with left-lateral positive); c Slip vector distribution

subfaults added and near field data adopted. But such detailed rupture cannot be resolved in our model for tightly smoothing constraints and near, intermediate, and far-field densely geodetic data used. We pay more emphasis on large scale feature of the rupture.

Our estimate of the total seismic moment accumulated over the entire rupture plane is $\sim 8.2 \pm 0.05 \times 10^{22} \mathrm{~N} \mathrm{~m}$, equivalent to the energy release of a $M_{\mathrm{W}} 9.2$ earthquake. This result should be robust because of good station coverage in the near, intermediate, and far fields of co-seismic deformation and the sensitivity of geodetic data to the geometry of the seismic rupture. Our estimated moment release is consistent with Vigny et al. $\left(2005,7.0 \times 10^{22} \mathrm{~N} \mathrm{~m}\right)$, Chlieh et al. $\left(2007,6.7-7.0 \times 10^{22}\right) \mathrm{N} \mathrm{m}$, Banerjee et al. (2007, $7.62 \times 10^{22} \mathrm{~N} \mathrm{~m}$ ), larger than that from the centroid moment magnitude $\left(4.0 \times 10^{22} \mathrm{~N} \mathrm{~m}\right)$ and from Rayleigh waves analysis (Vallee 2007, $5.6 \times 10^{22} \mathrm{~N} \mathrm{~m}$ ), smaller than that from normal-mode oscillation data modeling Stein and Okal $\left(2005,1.0 \times 10^{23} \mathrm{~N} \mathrm{~m}\right)$.

\section{Conclusions}

By using GPS, coral reef and remote sensing data, and a layered spherical instead of flat half space Earth model for deformation modeling, we firstly searched the co-seismic slip geometry model. Although large undulation of the postfit residual with different fault shape, one model is globally founded with the minimum postfit residuals, which shows possibility to estimate fault geometry from densely distributed geodetic data in near, intermediate, and far field. The geometry model with dip angle linearly increases along strike from $4.3^{\circ}$ in top southernmost patch to $4.5^{\circ}$ in top northernmost patch and dip angle linearly increased to $27^{\circ}$ in bottom southernmost patch and $26^{\circ}$ in bottom northernmost patch may reflect the reality of the rupture geometry (slab geometry). Then, by using the rupture geometry, the slip distribution is obtained, which shows that dominant thrust slip accompanied with meter level right-lateral slip occurred on the searched geometry model. The moment release is $8.2 \pm 0.05 \times 10^{22} \mathrm{~N} \mathrm{~m}$, corresponding to a $M_{\mathrm{W}} 9.2$ earthquake. The new established rupture model from good converge of geodetic data and more realistic spherical layered earth model may be help in post-seismic relaxation study (e.g., Pollitz et al. 2008), seismic hazard analysis in the future (e.g., Nalbant et al. 2005; Pollitz et al. 2006) and volcano eruption analysis (e.g., Walter and Amelung 2007).

Acknowledgments We thank Prof. Yun-tai Chen for his encouragement on seismic slip distribution inversion from geodetic data. Figures 1,2 and 5c are plotted by using GMT software (Wessel and 
Smith 1998). This work was supported by the Special Fund of Fundamental Scientific Research Business Expense for Higher School of Central Government (Projects for creation teams ZY20110101), NSFC 41090294 and talent selection and training plan project of Hebei university.

Open Access This article is distributed under the terms of the Creative Commons Attribution 4.0 International License (http://creativecommons.org/licenses/by/4.0/), which permits unrestricted use, distribution, and reproduction in any medium, provided you give appropriate credit to the original author(s) and the source, provide a link to the Creative Commons license, and indicate if changes were made.

\section{References}

Altamimi Z, Sillard P, Boucher P (2002) ITRF2000: a new release of the international Terrestrial Reference Frame for earth science applications. J Geophys Res 107(B10):2214. doi:10.1029/ 2001JB000561

Ammon CJ, Ji C, Thio H-K, Robinson D, Ni S, Hjorleifsdottir V, Kanamori H, Lay T, Das S, Helmberger D, Ichinose G, Polet J, Wald D (2005) Rupture process of the 2004 Sumatra-Andaman earthquake. Science 308:1133-1139

Banerjee P, Pollitz FF, Bürgmann R (2005) The size and duration of the Sumatra-Andaman earthquake from far-field static offsets. Science 308:1769-1772

Banerjee P, Pollitz FF, Nagarajan B, Bürgmann R (2007) Coseismic slip distributions of the 26 December 2004 Sumatra-Andaman and 28 March 2005 Nias earthquakes from GPS static offsets. Bull Seismol Soc Am 97:S86-S102

Bilham R (2005) A flying start, then a slow slip. Science 308: $1126-1127$

Biswas NN, Knopoff L (1970) Exact earth-flattening calculation for Love waves. Bull Seismol Soc Am 60:1123-1137

Chlieh M, Avouac J-P, Hjorleifsdottir V, Song T-R, Ji C, Sieh K, Sladen A, Hebert H, Prawirodirdjo L, Bock Y, Galetzka J (2007) Coseismic slip and afterslip of the great $\left(M_{\mathrm{W}}\right.$ 9.15) Sumatra-Andaman earthquake of 2004. Bull Seismol Soc Am 97:S152-S173

Gahalaut VK, Nagarajan B, Catherine JK, Kumar S (2006) Constraints on 2004 Sumatra-Andaman earthquake rupture from GPS measurements in Andaman-Nicobar Islands. Earth Planet Sci Lett 242:365-374

Gahalaut VK, Catherine JK, Jade S, Gireesh R, Gupta DC, Narsaiah M, Ambikapathy A, Bansal A, Chadha RK (2008) No evidence of unusually large postseismic deformation in Andaman region immediately after 2004 Sumatra-Andaman earthquake. Geophys Res Lett 35:L10307. doi:10.1029/2008GL033704

Herring TA (2002) GLOBK: Global Kalman filter VLBI and GPS analysis program, version 10.0. Mass Inst of Technol, Cambridge

King RW, Bock Y (2000) Documentation for the GAMIT GPS analysis software, release 10.0. Mass Inst of Technol, Cambridge

Lay T, Kanamori H, Ammon CJ, Nettles M, Ward SN, Aster RC, Beck SL, Bilek SL, Brudzinski MR, Butler R, DeShon HR, Ekstrom G, Satake K, Sipkin S (2005) The great Sumatra-Andaman earthquake of 26 December 2004. Science 308:1127-1133

Meltzner AJ, Sieh K, Abrams M, Agnew DC, Hudnut KW, Avouac J-P, Natawidjaja DH (2006) Uplift and subsidence associated with the great Aceh-Andaman earthquake of 2004. J Geophys Res 111:B02407. doi:10.1029/2005JB003891

Nalbant SS, Steacy S, Sieh K, Natawidjaja D, McCloskey J (2005) Earthquake risk on the Sunda trench. Nature 435:756-757

Ni S, Kanamori H, Helmberger D (2004) Energy radiation from the Sumatra earthquake. Nature 434:582
Niu ZJ, Wang M, Sun HR, Sun JZ, You XZ, Gan WJ, Xue GJ, Hao JX, Xin SH, Wang YQ, Wang YX, Li B (2005) Contemporary velocity field of crustal movement of Chinese mainland from Global Positioning System measurements. Chin Sci Bull 50(8):939-940

Park J, Song TRA, Tromp J, Okal E, Stein S, Roult G, Clevede E, Laske G, Kanamori H, Davis P, Berger J, Braitenberg C, Camp MV, Lei X, Sun H, Xu H, Rosat S (2005) Earth's free oscillations excited by the 26 December 2004 Sumatra-Andaman earthquake. Science 308:1139-1144

Pietrzak J, Socquet A, Ham D, Simons W, Vigny C, Labeur RJ, Schrama E, Stelling G, Vatvani D (2007) Defining the source region of the Indian Ocean Tsunami from GPS, altimeters, tide gauges and tsunami models. Earth Planet Sci Lett 261:49-64

Pollitz FF, Banerjee P, Bürgmann R, Hashimoto M, Chhoosakul N (2006) Stress changes along the Sunda trench following the 26 December 2004 Sumatra-Andaman and 28 March 2005 Nias earthquakes. Geophys Res Lett 33:L06309

Pollitz FF, Banerjee P, Grijalva K, Nagarajan B, Bürgmann R (2008) Effect of 3-D viscoelastic structure on post-seismic relaxation from the $2004 M=9.2$ Sumatra earthquake. Geophys J Int 173:189-204

Prawirodirdjo L, Bock Y, McCaffrey R, Genrich J, Calais E, Stevens C, Puntodewo SSO, Subarya C, Rais J, Zwick P, Fauzi (1997) Geodetic observations of interseismic strain segmentation at the Sumatra subduction zone. Geophys Res Lett 24(21):2601-2604

Rhie J, Dreger DS, Bürgmann R, Romanowicz B (2007) Slip of the 2004 Sumatra-Andaman earthquake from joint inversion of long period global seismic waveforms and GPS static offsets. Bull Seismol Soc Am 97:S115-S127

Shearer P, Bürgmann R (2010) Lessons learned from the 2004 Sumatra-Andaman megathrust rupture. Annu Rev Earth Planet Sci 38:103-131

Shen ZK, Jackson DD, Feng Y, Cline M, Kim M, Fang P, Bock Y (1994) Postseismic deformation following the Landers earthquake, California, 28 June 1992. Bull Seismol Soc Am 84(3): 780-791

Sieh K (2005) Aceh-Anderman earthquake: what happened and what next? Nature 434:573-574

Simoes M, Avouac JP, Cattin R, Henry P (2004) The Sumatra subduction zone: a case for a locked fault zone extending into the mantle. J Geophys Res 109:B10402. doi:10.1029/2003JB002958

Stein S, Okal EA (2005) Speed and size of the Sumatra earthquake. Nature 434:581-582

Subarya C, Chlieh M, Prawirodirdjo L, Avouac JP, Bock Y, Sieh K, Meltzner AJ, Natawidjaja DH, McCaffrey R (2006) Plateboundary deformation associated with the great SumatraAndaman earthquake. Nature 440(2):46-51

Tsai VC, Nettles M, Ekstrom G, Dziewonski AM (2005) Multiple CMT source analysis of the 2004 Sumatra earthquake. Geophys Res Lett 32:L17304. doi:10.1029/2005GL023813

Vallee M (2007) Rupture properties of the giant Sumatra earthquake imaged by empirical Green's function analysis. Bull Seismol Soc Am 97:S103-S114

Vigny C, Simons WJF, Abu S, Bamphenyu R, Satirapod C, Choosakul N, Subarya C, Socquet A, Omar K, Abidin HZ, Ambrosius BAC (2005) Insight into the 2004 Sumatra-Andaman earthquake from GPS measurements in southeast Asia. Nature. doi:10.1038/nature03937

Walter TR, Amelung F (2007) Volcanic eruptions following M9 megathrust earthquakes: implications for the Sumatra-Andaman volcanoes. Geology 35:539-542. doi:10.1130/G23429A.1

Wan YG, Shen Z-K, Wang M, Zhang ZS, Gan WJ, Wang QL, Sheng SZ (2008) Coseismic slip distribution of the 2001 Kunlun mountain Pass west earthquake constrained using GPS and 
InSAR data. Chin J Geophys 51(4):1074-1084 (In Chinese with English abstract)

Wessel P, Smith WMF (1998) New improved version of generic mapping tools released. EOS Trans 79:579
Zeng Y (2001) Viscoelastic stress-triggering of the 1999 Hector Mine earthquake by the 1992 Landers earthquake. Geophys Res Lett 28:3007-3010 